\title{
Pemberdayaan Ekonomi Warga Melalui Usaha Produktif Embuatan "Jahe Bubuk Instan"
}

\author{
Alien Akmalia1*, Rita Kusumawati² \\ 1. Prodi Manajemen, Fakultas Eonomi dan Bisnis, Universitas Muhammadiyah Yogyakarta, Jalan Brawijaya, Kasihan, Bantul, Yogyakarta \\ 55183 Hp. 082138170869 \\ 2 Universitas Muhammadiyah Yogyakarta, Jalan Brawijaya, Kasihan, Bantul, Yogyakarta 55183 \\ Email: alien_akmalia@umy.ac.id \\ DOI: 10.18196/ppm.32.216
}

\begin{abstract}
Abstrak
Kegiatan pengabdian ini dilatarbelakangi dengan adanya permasalahan yang dihadapi oleh warga Dusun Penggung, Desa Giripurwo, Kecamatan Girimulyo terutama ibu-ibu yang tergabung dalam kelompok PKK Penggung. Permasalahan yang dihadapi khalayak sasaran adalah pada aspek produksi dan aspek pemasaran. Khalayak sasaran belum memiliki kemampuan mengolah jahe bubuk instan dan minimnya pengetahuan pentingnya pemasaran dalam meningkatkan penjualan. Tujuan dari kegiatan pengabdian ini adalah untuk memberikan kemampuan pengolahan jahe menjadi produk jahe bubuk instan yang memiliki nilai jual sehingga bisa meningkatkan perekonomian warga. Metode yang digunakan dalam kegiatan ini adalah dengan metode praktik langsung, pelatihan, dan pendampingan. Hasil kegiatan pengabdian ini yaitu: (1) kelompok sasaran dapat mengolah jahe menjadi jahe bubuk instan yang layak jual (2) kelompok sasaran memiliki pengetahuan yang memadai tentang pentingnya pemasaran dalam meningkatkan penjualan produk. Implikasi dari kegiatan pengabdian ini dapat memberikan pengetahuan dan wawasan tentang pengolahan maupun pentingnya pemasaran. Produk jahe instan ini diharapkan bisa menjadi minuman khas Penggung. Selain itu, potensi menjadikan jahe bubuk instan khas penggung ini sebagai oleh-oleh khas Dusun Penggung sangat besar, mengingat di perbatasan dusun ini ada wisata waduk yang sedang dikembangkan oleh pemerintah desa. Kegiatan ini sudah berjalan lancar sesuai dengan yang direncanakan dan kelompok sasaran bisa mengaplikasikan rangkaian kegiatan pengabdian yang telah dilaksanakan.
\end{abstract}

Kata Kunci: Jahe Bubuk Instan, Produksi, Pemasaran

\section{Pendahuluan}

Kelompok sasaran yang dituju dalam program KKN-PPM ini adalah kelompok PKK Dusun Penggung yang diketuai oleh Ibu Suminem. Kegiatan PKK Ibu-Ibu di dusun ini cukup aktif. Salah satu kegiatannya adalah penggiatan penanaman Tanaman Obat Keluarga (TOGA) di pekarangan rumah masing-masing. Kegiatan ini sebenarnya merupakan program Desa Girimulyo bagi seluruh warganya tidak terkecuali Dusun Penggung. Berdasarkan komunikasi langsung dengan Bapak Paijan (Kadus Penggung) menceritakan bahwa Ibu-Ibu PKK dan beberapa perangkat Dusun pernah melakukan studi banding tentang penanaman Tanaman Obat Keluarga (TOGA) ke Kabupaten Gunung Kidul. Berdasarkan info yang diperoleh, setelah melakukan studi banding tersebut para peserta studi banding sangat tertarik dan bersemangat untuk bisa mengikuti jejak lokasi studi banding tersebut. Akan tetapi penerapannya ternyata tidak semudah yang dibayangkan. Warga menghadapi beberapa kendala dalam aktivitas penanaman TOGA dan rencana-rencana kegiatan turunannya. Warga berkeinginan untuk bisa mengolah jahe menjadi jahe bubuk instan yang bisa dipasarkan.

Tanaman TOGA utamanya dalam hal ini adalah jahe merah memiliki khasiat yang luar biasa untuk kesehatan tubuh. Berdasarkan Mustinda dan Lusiana (2019) menyebutkan beberapa khasiat jahe merah diantaranya: meredakan mual, meredakan nyeri, mengurangi peradangan, memperkuat kekebalan tubuh, anti aging alami, mencegah inflamasi usus dan meningkatkan kesuburan. Berdasarkan pada khasiat yang banyak bagi kesehatan tersebut, tanaman jahe merah dipilih sebagai bahan dasar yang akan diolah menjadi minuman instan yang memiliki nilai jual. Khalayak sasaran akan diberikan pelatihan pengolahan jahe merah menjadi bubuk jahe merah. Masalah utama yang akan diselesaikan melalui program KKN-PPM disajikan pada tabel 1 berikut: 
Tabel 1. Prioritas Masalah

\begin{tabular}{|l|l|}
\hline No. & \multicolumn{1}{|c|}{ Prioritas Masalah } \\
\hline 1. & $\begin{array}{l}\text { Belum memiliki kemampuan dan keterampilan yang memadai untuk } \\
\text { mengolah produk hasil TOGA terutama jahe merah. }\end{array}$ \\
\hline 2. & $\begin{array}{l}\text { Belum memiliki pengetahuan yang memadai tentang pemasaran } \\
\text { produk }\end{array}$ \\
\hline
\end{tabular}

Kemampuan khalayak sasaran untuk mengolah produk bubuk jahe merah instan saja belum cukup. Masih diperlukan kemampuan pendukung lain yang terkait dengan pemasaran produk. Menurut Kotler dan Keller (2009) menyatakan bahwa pemasaran adalah suatu proses sosial dan manajerial yang di dalamnya individu dan kelompok mendapatkan apa yang mereka butuhkan dan inginkan dengan menciptakan, menawarkan dan menukarkan produk dan jasa yang bernilai dengan pihak lain.

Kerangka Teoretis:

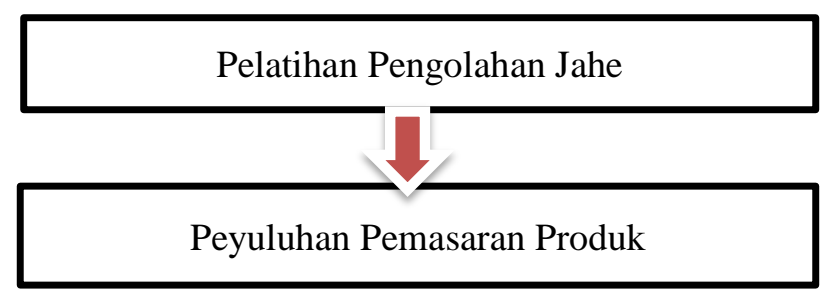

Lembaga yang menjadi mitra dalam program KKN-PPM ini adalah kelompok PKK Ibu-Ibu Dusun Penggung, Desa Giripurwo, Kecamatan Girimulyo, Kulonprogo, Daerah Istimewa Yogyakarta. Kabupaten Kulon Progo terletak pada posisi antara 7038'42" -7059'3" Lintang Selatan dan 11001'37" 110016'26" Bujur Timur. Luas kabupaten ini yaitu 586,27 km2. Kabupaten ini berbatasan dengan Kabupaten Sleman dan Kabupaten Bantul di timur, Samudra Hindia di Selatan, Kabupaten Purworejo di Barat, serta Kabupaten Magelang di Utara. Kelompok PKK ini di ketuai oleh Ibu Suminem yang tidak lain merupakan Istri Kepala Dusun Penggung (Bapak Paijan). Jumlah keseluruhan anggota kelompok PKK ini kurang lebih berjumlah 107 anggota. Dari sekian banyak anggota tersebut beberapa tidak aktif dalam kegiatan-kegiatan yang diadakan. Berdasarkan hasil komunikasi langsung dengan Ibu Suminem, jumlah anggota yang aktif kurang lebih sebanyak 60 sampai 70 anggota. Mitra yang akan dilibatkan dalam program KKN-PPM ini adalah seluruh anggota kelompok PKK Ibu-Ibu Dusun Penggung yang aktif.

Tujuan dari kegiatan pengabdian ini adalah untuk memberikan kemampuan pengolahan jahe menjadi produk jahe bubuk instan yang memiliki nilai jual sehingga bisa meningkatkan perekonomian warga. Khalayak sasaran tidak hanya akan dibekali cara pengolahan produk jahe bubuk instan, namun juga diberi penyuluhan tentang pentingnya pemasaran untuk meningkatkan penjualan.

\section{Metode Pelaksanaan}

Kegiatan pengabdian masyarakat di Dusun Penggung dilaksanakan dalam beberapa tahapan, sebagaimana tersaji pada began 1 berikut:

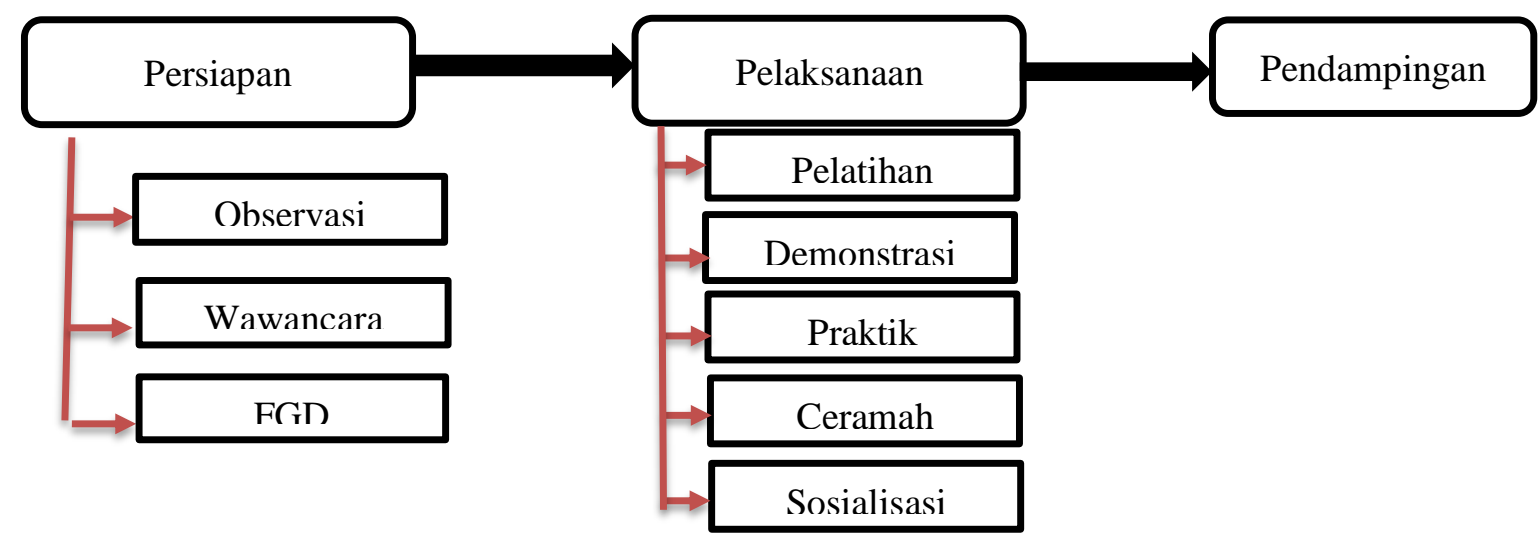

Bagan 1. Tahapan Pelaksanaan Kegiatan 
Sebelum mengusulkan program yang akan dijalankan, dilakukan observasi langsung ke lapangan untuk menggali potensi serta permasalahan yang ada di wilayah khalayak sasaran. Selain melakukan pengamatan langsung di lokasi, wawancara langsung dengan beberapa perangkat dusun seperti bapak Kadus, Ketua PKK maupun warga sekitar yang dijumpai saat terjun di lapangan juga dilakukan. Hal ini dilakukan supaya tidak terjadi ketidaksesuaian program yang diusulkan dengan kebutuhan khalayak sasaran. Kegiatan yang dilaksanakan dibagi menjadi dua tahap, yaitu tahap persiapan dan pelaksanaan. Kegiatan pada tahap persiapan meliputi: Observasi lapangan, wawancara langsung dan Focus Group Discussion. Pada tahap pelaksanaan kegiatan, dilakukan dengan beberapa metode, yang terdiri dari: Pelatihan, Demonstrasi, Praktik, Ceramah, dan Sosialisasi.

Khalayak sasaran dalam kegiatan ini yaitu kelompok PKK Dusun Penggung. Pemilihan responden ini dilakukan atas saran dari Kepala Dusun Penggung, dengan mendasarkan pada potensi yang dimiliki oleh kelompok PKK. Khalayak sasaran dibimbing untuk bisa memproduksi jahe bubuk instan. Peralatan yang digunakan seperti, blender, wajan, sutil, kompor dan sebagainya.

Proses pembuatan jahe merah serbuk melalui beberapa tahapan yaitu sebagai berikut :

a. Kupas kulit jahe, kemudian potong jahe menjadi bagian - bagian yang kecil.

b. Jahe yang telah di potong - potong menjadi bagian kecil dihaluskan dengan menggunakan blender, kemudian tambahkan air dengan perbandingan $1: 2$ antara jahe dan air, misalkan untuk 500 gr jahe, gunakan 1 liter air.

c. Pisahkan antara ampas jahe dengan air hasil campuran tadi sehingga hanya tersisa air jahe saja.

d. Setelah dipisahkan antara ampas dan air nya, kemudian masak air jahe dengan api yang sangat kecil.

e. Sembari diaduk, rebusan air jahe di beri gula dengan perbandingan yaitu 1: 2, lalu tambahkan daun pandan untuk wangi-wangian

f. Aduk terus rebusan tadi hingga perlahan - lahan air rebusan menjadi asat dan menjadi padat kemudian menjadi serbuk - serbuk halus karena hasil kristalisasi dari gula yang dimasak terus - menerus.

g. Setelah menjadi serbuk, sebenarnya olahan jahe sudah siap di packing, tapi akan lebih baik jika serbuk yang telah jadi tadi dihaluskan kembali dengan blender atau dengan penumbuk agar lebih halus lagi.

h. Setelah sangat halus maka serbuk pun sudah siap untuk masuk ke tahap pengemasan dan labeling.

\section{Hasil dan Pembahasan}

\section{Pelatihan pengolahan jahe merah menjadi bubuk jahe merah instan.}

Pelatihan pengolahan jahe merah menjadi jahe bubuk instan berhasil menarik antusiasme tinggi dari warga. Hal ini dapat dibuktikan dengan banyaknya warga yang mengikuti pelatihan ini, yaitu sebanyak 37 anggota PKK warga Dusun Penggung. Terselenggaranya kegiatan ini, berangkat dari kebutuhan warga akan keterampilan pengolahan tanaman TOGA. Dalam kurun waktu kurang lebih satu tahun terakhir ini, Desa Giripurwo sedang menggalakkan program penanaman TOGA di lahan pekarangan warga, tidak terkecuali Dusun Penggung. Hampir seluruh warga Dusun Penggung memiliki tanaman TOGA di pekarangan rumah masing-masing, namun belum ada warga yang memiliki keterampilan untuk mengolah TOGA. Oleh karena itu, dalam kegiatan ini warga diberikan keterampilan pengolahan tanaman TOGA khususnya jahe / jahe merah. 


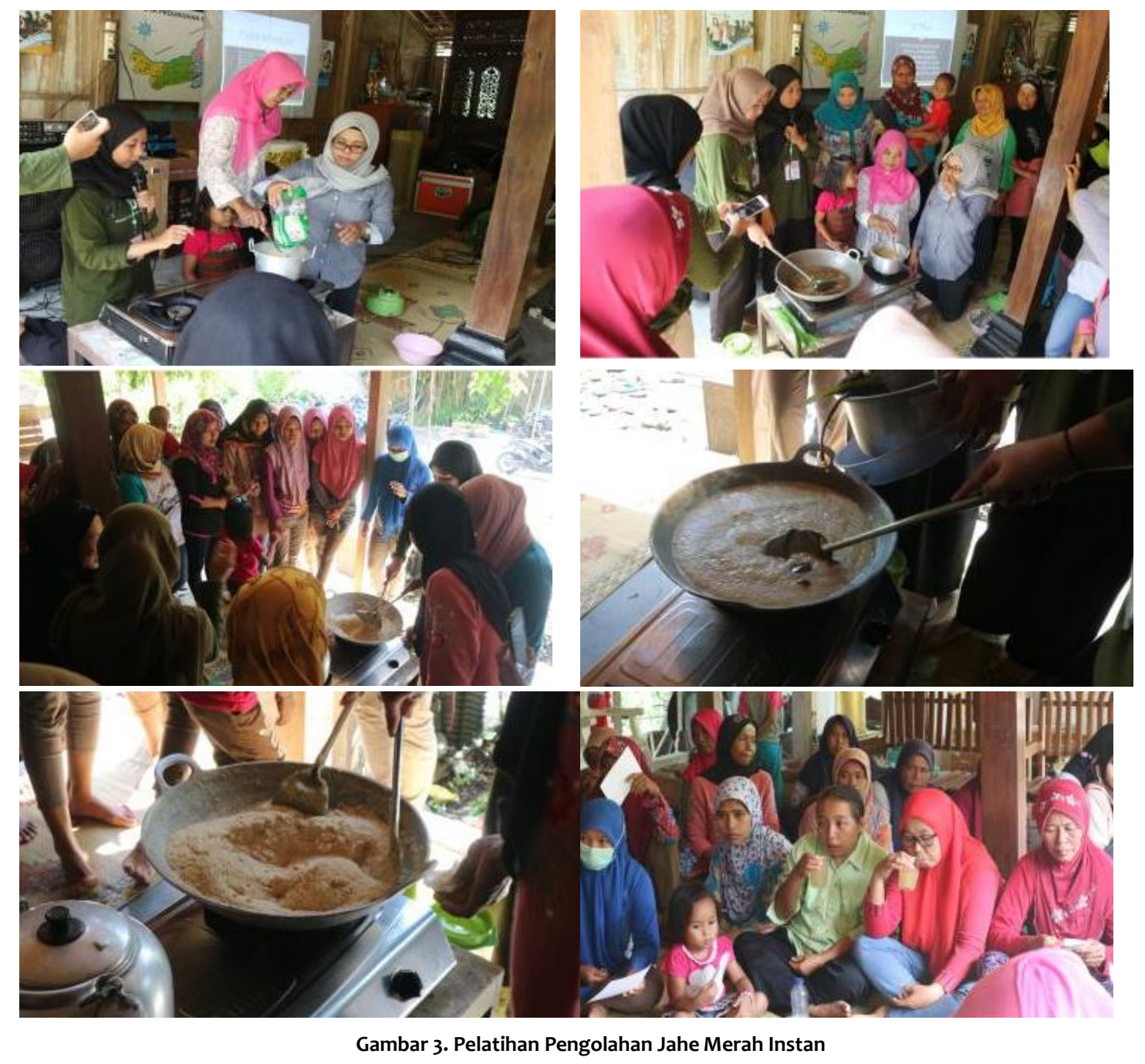

Pelatihan pengolahan jahe merah instan, dilakukan dengan memberikan penjelasan atau sosialisasi terlebih dahulu tentang langkah-langkah yang akan dilakukan. Setelah warga memahami tahapan-tahapan pengolahan jahe bubuk instan tersebut, pelatihan dilanjutkan dengan demonstrasi pembuatan jahe merah bubuk instan.

Demonstrasi pembuatan jahe bubuk instan berjalan dengan lancar. Peserta pelatihan sangat antusias mengikuti jalannya kegiatan. Bahkan ada beberapa peserta yang memohon izin untuk ikut serta atau terlibat dalam emonstrasi pembuatan produk olahan jahe merah tersebut. Setelah proses pembuatan jahe instan bubuk selesai dilakuakan, seluruh peserta diberikan kesempatan untuk mencoba 'wedang jahe' yang telah didemonstrasikan. Peserta pelatihan memberikan komentar yang positif terkait cita rasa 'wedang jahe' hasil pelatihan yang mereka minum. Peserta pelatihan sangat bersemangat dan memiliki motivasi untuk mencoba membuatnya di rumah masing-masing.

\section{Pelatihan pentingnya pemasaran untuk meningkatkan penjualan}

Menurut Kotler dan Amstrong (2012) mendefinisikan pemasaran sebagai proses dimana perusahaan menciptakan nilai bagi pelanggan dan membangun hubungan pelanggan yang kuat untuk menangkap nilai dari pelanggan sebagai imbalan. Berdasarkan pada definisi ini, maka dapat diartikan bahwa memiliki kemampuan memproduksi suatu barang saja belum cukup. Pemilik usaha juga harus memiliki kemempuan pemasaran yang baik termasuk khalayak sasaran yang didiampingi pada kegiatan pengabdian ini. Khalayak sasaran harus mampu menciptakan nilai bagi pembelinya serta apat menjalin hubungan yang kuat dengan para pelanggannya. 
Pelatihan ini sudah berjalan dengan lancar dan sesuai rencana. Para peserta sangat antusias mengikuti pelatihan sampai selesai acara. Peserta juga aktif bertanya terkait materi yang disampaikan oleh narasumber. Peserta dapat memperoleh wawasan tentang pentingnya mengelola pelanggan dan menciptakan nilai bagi pelanggan sehingga produk jahe yang akan dijual tersebut dapat terus meningkat penjualannya.
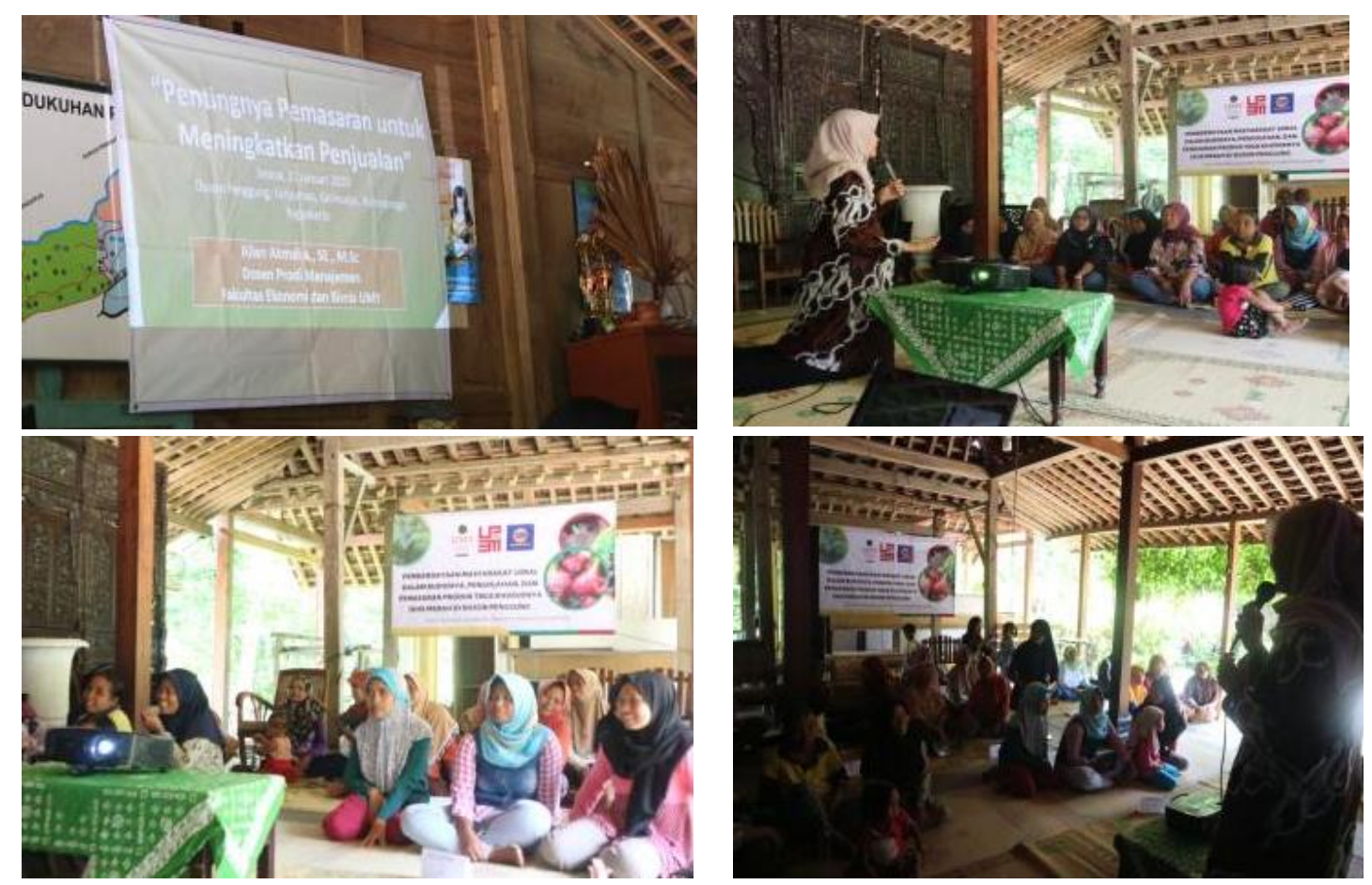

Gambar 3. Pelatihan pentingnya pemasaran untuk meningkatkan penjualan

\section{Pendampingan}

Kegiatan pendampingan dilakukan setelah seluruh rangkaian program pelatihan diberikan. Pendampingan ditujukan utuk mendampingi khalayak sasaran yang mengalami kesulitan dalam mengaplikasikan materi yang telah disampaikan dalam pelatihan. Khalayak sasaran dapat bertanya Ketika ada kegiatan berikutnya di lokasi, ataupun dapat berkonsultasi melalui Whatsapp atau telepon.
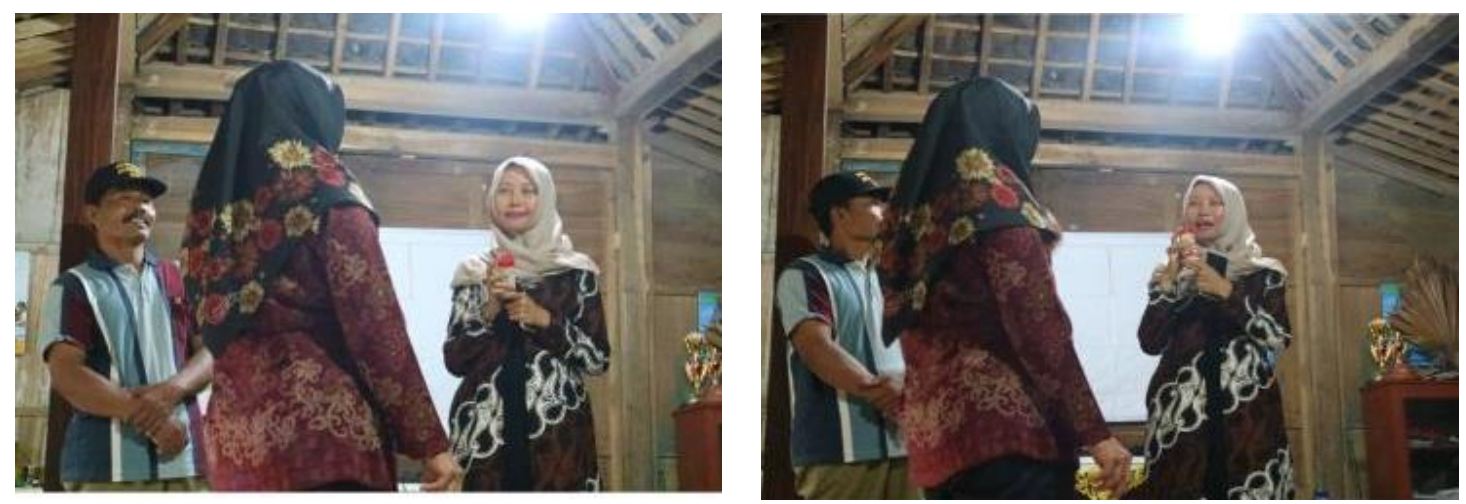

Gambar 6. Kegiatan pendampingan yang dilakukan dengan salah satu warga yang menjadi penggerak PKK dan selama ini menangani usaha yang dijalankan ibu-ibu PKK Dusun Penggung 


\section{Simpulan}

Kegiatan pengabdian masyarakat yang dilakukan bagi kelompok PKK Dusun Penggung telah berjalan lancar sesuai rencana. Khalayak sasaran telah memiliki kemampuan untuk mengolah jahe bubuk instan yang memiliki nilai jual. Selain itu, khalayak sasaran juga telah memiliki wawasan pentingnya kemampuan untuk dapat menciptakan nilai bagi pelanggan serta membina hubungan yang kuat dengan pelanggan. Setelah selesai kegiatan ini, khalayak sasaran sudah mampu melakukan produksi jahe bubuk instan secara mandiri, dengan kegiatan pendampingan yang dilakukan sebelumnya.

\section{Ucapan Terima Kasih}

Pada kesempatan ini kami mengucapkan terimakasih kepada:

1. LP3M UMY yang telah mendanai program pengabdian, dengan No. SK Kepala LP3M: 031/PEN-LP3M/I/2020

2. Kadus Penggung

3. Ibu Suminem selaku ketua PKK Dusun Penggung

4. Mahasiswa KKN kelompok 126 UMY

5. Semua pihak yang telah membantu terlaksananya program pengabdian ini.

\section{Daftar Pustaka}

Kotler dan Keller. (2009). Manajemen Pemasaran. Jilid 1. Edisi ke 13. Jakarta: Erlangga.

Kotler, Philip dan Armstrong, Gary. 2012. Principles of Marketing. New Jersey: Prentice Hall.

Mustinda, Lusiana (2019), 7 Manfaat Jahe Merah Untuk Kesehatan, https://food.detik.com/info-sehat/d-4806674/7-manfaat-jahe-merah-untuk-kesehatan 